\title{
En espèce ou en nature ? Les présents, l'imprévoyance et l'évolution idéologique de la politique indienne pendant la première moitié du $\mathrm{XIX}^{\mathrm{e}}$ siècle
}

\section{Brian Gettler}

Volume 65, numéro 4, printemps 2012

URI : https://id.erudit.org/iderudit/1021048ar

DOI : https://doi.org/10.7202/1021048ar

Aller au sommaire du numéro

Éditeur(s)

Institut d'histoire de l’Amérique française

ISSN

0035-2357 (imprimé)

1492-1383 (numérique)

Découvrir la revue

Citer cet article

Gettler, B. (2012). En espèce ou en nature ? Les présents, l'imprévoyance et l'évolution idéologique de la politique indienne pendant la première moitié du $\mathrm{XIX}^{\mathrm{e}}$ siècle. Revue d'histoire de l'Amérique française, 65(4), 409-437. https://doi.org/10.7202/1021048ar

\section{Résumé de l'article}

Cet article porte sur la distribution des présents aux Premières Nations du Canada par l'État impérial britannique pendant la première moitié du XIX siècle. En analysant les débats entourant une proposition de remplacer des biens matériels distribués en tant que présents par de l'argent, l'auteur observe le développement d'un consensus au sein des autorités métropolitaines et coloniales, mais qui est également partagé par les philanthropes et même par certains Autochtones, selon lequel les Amérindiens, à l'instar des pauvres du milieu urbain, sont imprévoyants par nature. Ces mêmes acteurs croient que les Autochtones ont besoin de la direction et du soutien de l'État paternel, une conviction qui demeure au coeur même de la politique indienne canadienne jusqu'à nos jours. L'article affirme que le discours prônant la « civilisation » des Premières Nations, tenu par les fonctionnaires et les philanthropes, s'appuie sur cette conviction et ainsi participe à former l'idéologie justifiant l'intervention étatique dans les communautés autochtones et la mise en tutelle de ces dernières.
Tous droits réservés (C Institut d’histoire de l’Amérique française, 2013
Ce document est protégé par la loi sur le droit d'auteur. L'utilisation des services d’Érudit (y compris la reproduction) est assujettie à sa politique d'utilisation que vous pouvez consulter en ligne. 


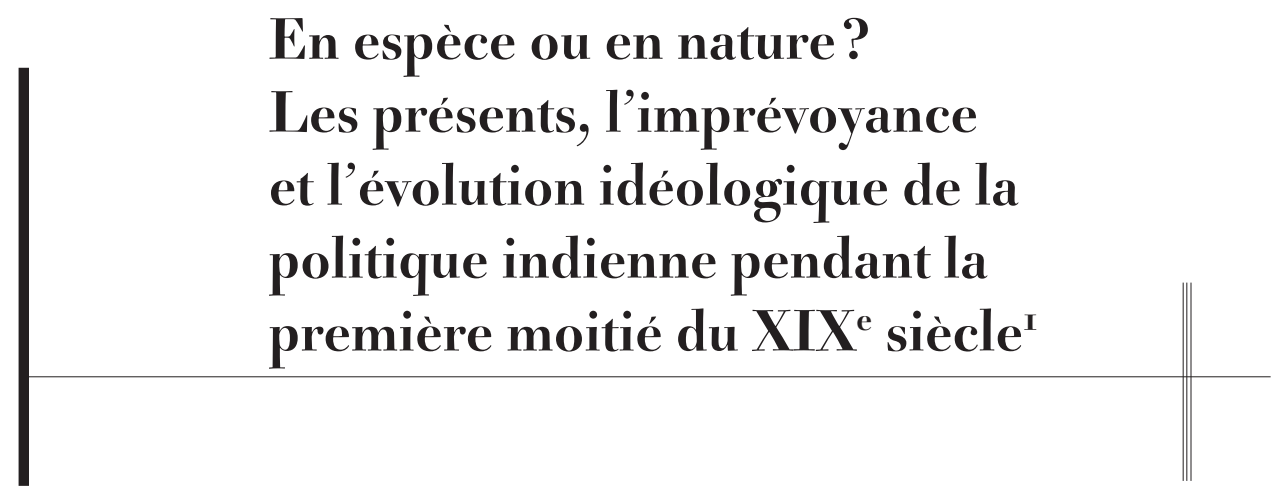

\author{
BRIAN GETTLER \\ Département d'histoire \\ Université du Québec à Montréal
}

RÉsumÉ - Cet article porte sur la distribution des présents aux Premières Nations du Canada par l'État impérial britannique pendant la première moitié du XIXe siècle. En analysant les débats entourant une proposition de remplacer des biens matériels distribués en tant que présents par de l'argent, l'auteur observe le développement d'un consensus au sein des autorités métropolitaines et coloniales, mais qui est également partagé par les philanthropes et même par certains Autochtones, selon lequel les Amérindiens, à l'instar des pauvres du milieu urbain, sont imprévoyants par nature. Ces mêmes acteurs croient que les Autochtones ont besoin de la direction et du soutien de l'État paternel, une conviction qui demeure au cœur même de la politique indienne canadienne jusqu'à nos jours. L'article affirme que le discours prônant la «civilisation» des Premières Nations, tenu par les fonctionnaires et les philanthropes, s'appuie sur cette conviction et ainsi participe à former l'idéologie justifiant l'intervention étatique dans les communautés autochtones et la mise en tutelle de ces dernières.

ABSTRACT - This article concerns the distribution of presents by the British imperial state to First Nations in Canada during the first half of the nineteenth century. Through an analysis of the proposed replacement by money of the material goods distributed as presents, it observes the development of the consensus held by metropolitan and colonial authorities, philanthropists and even by certain Amerindians that Aboriginal peoples, like the urban poor, were improvident by nature. This consensus gave rise to the conviction held by many of

1. L'auteur souhaite remercier Jacinthe Archambault, Mathieu Chaurette et les évaluateurs anonymes pour leur lecture attentive de la première version de cet article ainsi que pour leurs commentaires constructifs. 
these same actors that Aboriginal peoples required guidance and support from the state, a conviction that remains at the heart of Canadian Indian policy to this day. This article argues that the discourse of civil servants and philanthropists asserting the need to "civilize" First Nations was based on this conviction and played a key role in generating the ideology that justified both state intervention in Aboriginal communities and Amerindians' status as legal minors.

$\mathrm{E}^{\mathrm{n}}$ n 1827, le comte de Dalhousie, gouverneur en chef de l'Amérique du Nord britannique, affirme que la pratique impériale de fournir «des présents utiles en paiement» aux Amérindiens tire ses origines d'un désir "d'éviter la tentation ${ }^{2}$ ». Ce faisant, Dalhousie dépeint ces présents comme une forme d'assistance sociale, exprimant ainsi à travers la politique indienne son adhésion à un ensemble conceptuel très répandu au $\mathrm{XIX}^{\mathrm{e}}$ siècle selon lequel la pauvreté et l'imprévoyance sont inextricablement liées. Dès la fin de l'ère victorienne, cette vision générale des Amérindiens et des plus démunis, considérés comme étant inaptes à gérer leurs affaires financières et même à manipuler de l'argent comptant, domine le champ d'assistance sociale au Canada ${ }^{3}$. Même si l'historiographie reconnaît l'influence que cette conception de l'imprévoyance a eue sur la provision de l'assistance, aucune étude n'a analysé son déploiement initial chez les Autochtones du Canada. En effet, la seule étude historique dédiée au développement de l'assistance sociale chez les Premières Nations ne considère guère la période précédant la Confédération, donnant ainsi l'impression que la vision courante de l'Amérindien imprévoyant par nature n'est qu'un produit de la fin du XIX ${ }^{e}$ siècle ${ }^{4}$. Cette lacune historiographique ne permet ni d'établir les origines de l'assistance sociale fournie aux Amérindiens ni de comprendre le développement de l'idéo-

2. Traduction de l'auteur. Dans l'anglais original, Dalhousie écrit que «the system adopted in making useful presents as payment was intended expressly to avoid temptation and take away the means furnished to that dreadful state of brutal drunkenness, to which all Indians, men, women and children, give themselves». "Extract of a Despatch from Lord Dalhousie to Mr. Secretary Huskisson", 22 novembre 1827, dans Great Britain, Aboriginal Tribes (North America, New South Wales, Van Diemen's Land and British Guiana) (Londres, 1834), 6.

3. Sur l'évolution du débat canadien sur la pauvreté pendant les XIX et $\mathrm{XX}^{\mathrm{e}}$ siècles, voir Dennis Guest, The Emergence of Social Security in Canada (Vancouver, UBC Press, 1997), $3^{\mathrm{e}}$ éd. Même si cette conception des causes de la pauvreté serait détrônée au XXe siècle avec la montée de l'État-providence, la provision d'assistance monétaire demeurerait contestée jusqu'à nos jours. Pour un programme qui a en partie réussi à surmonter cette résistance au milieu du XXe siècle (les allocations familiales), voir Dominique Marshall, Aux origines sociales de l'État-providence. Familles québécoises, obligation scolaire et allocations familiales, 1940-1955 (Montréal, Presses de l'Université de Montréal, 1998).

4. Hugh Shewell, "Enough to Keep Them Alive»: Indian Welfare in Canada, 1873-1965 (Toronto, University of Toronto Press, 2004). 
logie soutenant l'action étatique à l'égard de ces derniers pendant le XIX siècle.

Cet article soutient que les discours de l'État, des philanthropes et des Autochtones à l'égard de l'argent et des présents au cours des années 1820 et 1830 contribuent à la redéfinition des Amérindiens comme étant imprévoyants par nature. Cette étude analyse les suites d'une proposition impériale, d'abord faite en 1827 , qui, dans le but de réduire les dépenses de la caisse impériale destinées au département des Affaires indiennes 5 , recommande de remplacer les présents distribués aux Autochtones de la vallée du Saint-Laurent et des Grands Lacs par de l'argent comptant. L'offre est toutefois mal reçue par les autorités coloniales ainsi que par la plupart des Amérindiens et des missionnaires. Les débats qui s'ensuivent révèlent une partie importante de l'idéologie contribuant à la formation et au développement de la politique indienne pendant la période - à savoir, la vision voulant que les Autochtones ont besoin de la direction et du soutien de l'État paternel, puisqu'ils sont naturellement imprévoyants. Suivant Philip J. Deloria, nous croyons que cette idéologie, dévoilée dans le contexte des débats sur la monétisation des présents par des hauts fonctionnaires impériaux et coloniaux, joue un rôle fondamental dans le maintien des relations de pouvoir inégales qui caractérisent le colonialisme en Amérique du Nord 6 .

Ce cas particulier illustre comment les idées sont énoncées et contribuent ultimement à la restructuration des relations humaines et à la perception du monde à travers le processus de formation idéologique ${ }^{7}$. Au sein des débats sur la commutation, on observe que l'image influente de l'Amérindien imprévoyant dote les administrateurs à la fois d'un outil pour penser la gestion des peuples autochtones et d'un moyen pour communiquer les fondements de cette gestion à l'opinion publique contemporaine $^{8}$. Cette idéologie, qui devient hégémonique au XIX ${ }^{\mathrm{e}}$ siècle, permet

5. Pendant la période étudiée, l'institution qui allait devenir plus tard au XIX siècle le département des Affaires indiennes est appelée le «Indian Department» ou les «Indian Affairs», tandis qu'en français elle est généralement connue sous l'étiquette du département des Sauvages. Pour des raisons de clarté, cet article adopte le nom utilisé le plus couramment dans l'historiographie soit le «département des Affaires indiennes".

6. Philip J. Deloria, Indians in Unexpected Places (Lawrence, University of Kansas Press, 2004), 7-11.

7. Pour une étude qui porte sur la matérialisation des idées par l'État, voir James C. Scott, Seeing Like a State: How Certain Schemes to Improve the Human Condition Have Failed (New Haven, Yale University Press, 1998).

8. Sur le rôle de l'idéologie dans le développement d'une politique autonome - à savoir, un système politique qui n'est pas "firmly embedded in Edmund Burke's golden assemblage of "ancient opinions and rules of life" " - voir, Clifford Geertz, "Ideology as a Cultural System », dans David E. Apter, dir., Ideology and Discontent (Londres, The Free Press of Glencoe, 1964), 47-76. Geertz décrit comment les 
aux administrateurs, philanthropes et politiciens de diagnostiquer un "problème" politique plus ou moins réel - l'imprévoyance des Amérindiens - tout en proposant un remède simple - un programme de "civilisation" visant à «élever» les Autochtones au même stade de développement que leurs voisins d'origine européenne. Les pouvoirs plus importants accordés par les législateurs coloniaux au département des Affaires indiennes à partir du milieu du XIX ${ }^{\mathrm{e}}$ siècle découlent ainsi de cette vision des Autochtones ${ }^{9}$. En ce sens, le consensus qui émerge des débats colonial-impérial, à l'effet que les Amérindiens sont prédisposés à l'imprévoyance, participe à la naturalisation de la distinction sociopolitique entre les Autochtones et tout autre Canadien, distinction sur laquelle le ministère des Affaires autochtones et Développement du Nord Canada continue de fonder sa légitimité de nos jours ${ }^{10}$.

L’imprévoyance que décèlent des observateurs du XIX ${ }^{\mathrm{e}}$ siècle chez les peuples autochtones est intimement liée à plusieurs autres représentations des Amérindiens et des pauvres. Parmi celles-ci, l’image des bénéficiaires de charité ou d'assistance sociale, jugés incapables de gérer leur argent de façon raisonnable et autonome, occupe une place de première importance ${ }^{11}$. En général, le remède à l'imprévoyance que proposent les commentateurs de l'ère victorienne (autant des philanthropes que des reli-

«images influentes» ("sausive images») permettent à l'opinion publique de saisir de façon sensible des questions politiques. Autrement dit, l'idéologie rend facilement intelligible des phénomènes sociaux, économiques et autres complexes, comme la pauvreté, tout en proposant une solution qui est généralement plutôt simple. Sur l'opinion publique et la manière dont ce concept s'est établi en tant que moyen privilégié par lequel l'État rend légitime ses décisions en Amérique du Nord britannique, voir Jeffrey L. McNairn, The Capacity to Judge: Public Opinion and Deliberative Democracy in Upper Canada, 1791-1854 (Toronto, University of Toronto Press, 2000).

9. Jean et John Comaroff affirment que l'hégémonie «exists in reciprocal interdependence with ideology: it is that part of a dominant worldview which has been naturalized and, having hidden itself in orthodoxy, no more appears as ideology at all». Jean Comaroff et John Comaroff, Of Revelation and Revolution, Christianity, Colonialism, and Consciousness in South Africa (Chicago, University of Chicago Press, 1991), 1:25. Concernant les changements législatifs du milieu du XIX ${ }^{\mathrm{e}}$ siècle, voir John S. Milloy, "The Early Indian Acts: Developmental Strategy and Constitutional Change», dans J. R. Miller, dir., Sweet Promises: A Reader on Indian-White Relations in Canada (Toronto, University of Toronto Press, 1991), 145-154.

10. Sur le processus général de naturalisation des institutions, voir Mary Douglas, Comment pensent les institutions (Paris, La Découverte, [1986] 1999). Ce ministère, l’héritier institutionnel du département des Affaires indiennes, existe entre autres afin « d'aider le gouvernement à respecter ses obligations et ses engagements envers les Premières Nations, les Inuits et les Métis ». "À propos d'AADNC», www.aadncaandc.gc.ca/fra/1100100010023/1100100010027 [consulté le 18 juin 2012]. Autrement dit, l'organisme continue de fonder sa légitimité sur une distinction nette entre les Autochtones et les autres citoyens canadiens.

11. Pour l'étude canonique du développement de cette idée, qui se concentre sur l'Angleterre du XIX siècle, voir Gertrude Himmelfarb, The Idea of Poverty: England in the Early Industrial Age (New York, Knopf, 1984). 
gieux ou des politiciens), au Canada comme ailleurs, se base sur la réforme morale et défend strictement l'assistance sous forme monétaire ${ }^{12}$. L'idée que les pauvres soient responsables de leur propre sort conforte certains stéréotypes déjà existants à l'égard des peuples autochtones, notamment ceux leur accordant une nature indolente et païenne.

Aux XVII ${ }^{e}$ et XVIII ${ }^{e}$ siècles, les commentateurs d'origine européenne partagent généralement la conviction que les hommes amérindiens manquent d'assiduité. Selon les conceptions culturelles européennes, les Premières Nations démontrent leur barbarisme en transgressant les rôles genrés et la hiérarchie sociale. En effet, tandis que les femmes amérindiennes du nord-est de l'Amérique du Nord cultivent dans les champs, les hommes chassent, activité de loisir par excellence réservée aux classes supérieures en Europe ${ }^{13}$. De plus, le manque évident d'éveil religieux chez les Amérindiens encourage les Européens à les caractériser de "pauvres Indiens ", ignorant les Saintes Écritures et ayant donc besoin de la charité, en l'occurrence morale et non pas matérielle ${ }^{14}$. Au lieu de célébrer les vertus des Autochtones comme a pu le faire à l'époque des Lumières, les commentateurs du XIX ${ }^{\mathrm{e}}$ siècle s'inspirent du progrès incarné par l'industrialisation et la supériorité apparente de la société occidentale afin de précipiter l'effondrement des Premières Nations. Ce faisant, ils délaissent la critique de la société décadente de l'Europe dressée notamment par Rousseau, incarnée par la figure édénique du «bon Sauvage», pour se tourner vers l'idée que les Amérindiens, visiblement en voie de disparition, méritent la pitié ${ }^{15}$. De cette façon, on dépeint les Autochtones

12. Mariana Valverde, "The Mixed Social Economy as a Canadian Tradition», Studies in Political Economy, 47 (été 1995): 33-60.

13. James Axtell, "The Invasion Within: The Contest of Cultures in Colonial North America», dans James Axtell, The European and the Indian: Essays in the Ethnohistory of Colonial North America (New York, Oxford University Press, 1981), 39-86.

14. Laura M. Stevens, The Poor Indians: British Missionaries, Native Americans, and Colonial Sensibility (Philadelphie, University of Pennsylvania Press, 2004).

15. Sur le «bon Sauvage», voir Robert F. Berkhofer, Jr., The White Man's Indian: Images of the American Indian from Columbus to the Present (New York, Vintage Books, 1979), 72-80. Sur la pensée victorienne voulant que les Autochtones sont en voie de disparition, voir Fiona J. Stafford, The Last of the Race: The Growth of a Myth from Milton to Darwin (Oxford, Clarendon Press, 1994). Pour une analyse de ce discours dans le contexte bas-canadien/ québécois, voir Véronique Rozon, Un dialogue identitaire: les Hurons de Lorette et les autres au XIX $X^{e}$ siècle, mémoire de maîtrise (histoire), Université du Québec à Montréal, 2005, 77-89 et «Pour une réflexion sur l’identité huronne au XIX ${ }^{\mathrm{e}}$ siècle: une analyse de la thématique du "dernier des Hurons" sous l'éclairage des théories de l'ethnicité», dans Alain Beaulieu et Maxime Gohier, dir., La recherche relative aux Autochtones: perspectives historiques et contemporaines (Montréal, Chaire de recherche du Canada sur la question territoriale autochtone, 2007), 223-261. 
comme étant imprévoyants et impuissants à renverser eux-mêmes leur déclin.

Toutefois, ce n'est pas seulement les Européens et les Euro-Canadiens qui utilisent l'imprévoyance imputée aux Amérindiens afin d'influencer le cours des relations coloniales. Tout comme l'inanition («starvation») dans le contexte de la traite des fourrures dans le Subarctique ${ }^{16}$, l'imprévoyance devient, au XIX ${ }^{\mathrm{e}}$ siècle, un concept autour duquel les autorités, les philanthropes et les Amérindiens peuvent rendre intelligibles les effets du colonialisme sur la population autochtone. Même si chacun comprend le "problème indien» de façon différente, ils se servent tous du consensus développé pendant la période - les peuples autochtones sont imprévoyants par nature -, pour se tailler une place dans la société coloniale. En effet, si les philanthropes, et plus tard l'État, instrumentalisent cette vision de l’Amérindien imprévoyant afin de rendre légitime leurs interventions auprès des Premières Nations, ces dernières rappellent en retour à la société coloniale leur droit à une forme de reconnaissance particulière - à savoir, les présents diplomatiques. Du point de vue amérindien, ces présents ne sont pas anodins puisqu'ils soulignent leur statut particulier dans la colonie et réaffirment leur existence en tant que communauté. D’ailleurs, l'État collabore activement avec les chefs amérindiens pendant la période pour que les présents deviennent de véritables marqueurs de l'identité amérindienne. Les individus qui refusent de suivre les consignes de leurs leaders verront le département supprimer leur nom de la liste des présents, liste qui constitue l'unique index des membres des bandes amérindiennes au Canada avant les réformes législatives de la deuxième moitié du XIX ${ }^{\mathrm{e}}$ siècle $^{17}$.

\section{LA NATURE DES PRÉSENTS DISTRIBUÉS AUX AMÉRINDIENS}

La distribution des présents aux Amérindiens occupe une place importante dans les relations européennes-autochtones en Amérique du Nord. Pendant les XVII et XVIII ${ }^{\mathrm{e}}$ siècles, les Français et les Britanniques utilisent largement les présents afin de former et de maintenir des alliances mili-

16. Mary Black-Rodgers, "Varieties of "Starving" : Semantics and Survival in the Subarctic Fur Trade, 1750-1850", Ethnohistory, 33,4 (automne 1986): 353-383.

17. Par exemple, lors d'un conflit interne à Lorette (aujourd'hui Wendake) dans les années 1840, le département des Affaires indiennes soutient l'autorité des chefs en suspendant la distribution « of Presents to Indians who resist the lawful commands of their particular Leaders or Grand Chiefs». Duncan C. Napier à Rowan W. Rowan, 10 janvier 1844, BAC, RG10, vol. 593, no. 52, bob. C-13378. 
taires avec des Premières Nations ${ }^{18}$. Dans le contexte spécifique de l'Amérique du Nord britannique, la distribution de présents atteint un statut sacro-saint au sein de la politique impériale à la suite du soulèvement de Pontiac - une insurrection panindienne engendrée en partie par la décision du général Jeffery Amherst d'abolir de tels présents après la guerre de Sept $\mathrm{Ans}^{19}$. Toutefois, la fin des conflits militaires impériaux en Amérique du Nord après la guerre de 1812-1814 amène les autorités britanniques à remettre en question la distribution des présents ${ }^{20}$. Les Amérindiens ne partagent cependant pas cette vision de la désuétude des présents, les interprétant de façon générale comme un signe de la bonne foi des Britanniques, signe nécessaire au maintien des relations ${ }^{21}$. Ainsi, les Autochtones tendent à concevoir les présents comme un don symbolique ayant un sens nettement plus profond que la simple valeur marchande, contrairement aux fonctionnaires britanniques qui leur accordent de plus en plus fréquemment une valeur monétaire au début du $\mathrm{XIX}^{\mathrm{e}}$ siècle $^{22}$. En effet, selon la plupart des Amérindiens du Bas et du HautCanada, les présents servent à entretenir un lien social avec l'État britannique.

18. Sur le système français, voir Catherine Desbarats, "The Cost of Early Canada's Native Alliances : Reality and Scarcity's Rhetoric", William \& Mary Quarterly, 52,4 (1995): 609-630; Gilles Havard, Empire et métissages: Indiens et Français dans le Pays d'en Haut, 1660-1715 (Sillery/Paris, Septentrion/Presses de l'Université Paris-Sorbonne, 2003) et Cornelius J. Jaenen, "The Role of Presents in the French-Amerindian Trade", dans Duncan Cameron, dir., Explorations in Canadian Economic History: Essays in Honour of Irene M. Spry (Ottawa, University of Ottawa Press, 1985), 231-250. Sur l'importance des présents dans la "matérialisation de la parole» - à savoir, la démonstration de sa véracité - lors des négociations diplomatiques dans le nord-est de l'Amérique du Nord, voir Jonathan C. Lainey, La "monnaie des Sauvages»: les colliers de wampum d'hier à aujourd'hui (Sillery, Septentrion, 2004), 50-53.

19. Gregory Evans Dowd, War Under Heaven: Pontiac, the Indian Nations and the British Empire (Baltimore, The Johns Hopkins University Press, 2002), 70-75 et Richard White, The Middle Ground: Indians, Empires, and Republics in the Great Lakes Region, 1650-1815 (New York, Cambridge University Press, 1991), 257-258 et 286-289. Sur la restauration des présents par le surintendant de la Northern Division du département des Affaires indiennes, sir William Johnson, en 1764, voir ibid., 310.

20. Sur le système britannique des présents à la suite de la guerre de 1812-1814, voir Catherine A. Sims, Algonkian-British Relations in the Upper Great Lakes Region: Gathering to Give and to Receive Presents, 1815-1843, thèse de doctorat (histoire), University of Western Ontario, 1992 et Anne Réthoré, La fin d'un symbole d'alliance. Les Britanniques et la politique de distribution des présents aux Amérindiens, 1815-1858, mémoire de maîtrise (histoire), Université de Rennes II et Université du Québec à Montréal, 2000.

21. Par exemple, pendant un conseil tenu en 1829 avec un représentatif britannique au sujet de l'établissement permanent de sa nation à côté de Sault-Sainte-Marie, Shingwaukonse affirme que «if the British proved faithful to their Native allies and continued to supply presents, he and his band would consider moving permanently to the Canadian shore». Janet E. Chute, The Legacy of Shingwaukonse: A Century of Native Leadership (Toronto, University of Toronto Press, 1998).

22. Sur le don chez les Hurons au début du Régime français, voir Denys Delâge, Le pays renversé. Amérindiens et Européens en Amérique du nord-est, 1600-1664 (Montréal, Boréal Express, 1985), 64-65. Comme nous verrons ci-dessous, les Amérindiens de la vallée du Saint-Laurent tiennent un discours sur les présents diplomatiques au début du XIX $\mathrm{X}^{\mathrm{e}}$ siècle qui s'apparente à cette vision coutumière iroquoienne. 
Toutefois, la valeur de ces présents n'est pas exclusivement symbolique; ils forment également une source non négligeable de revenus pour les Amérindiens. Au début des années 1840, une famille autochtone fictive de deux adultes et trois enfants dans le Haut-Canada obtient en présents approximativement sept pour cent de la valeur des produits vendus par une ferme "moyenne ${ }^{23}$ ». Ce pourcentage représente toutefois une sousestimation de la valeur des présents reçus par certaines catégories d'Amérindiens. Par exemple, en compensation pour des blessures infligées lors des campagnes militaires, des anciens combattants reçoivent ce que le département des Affaires indiennes appelle le "full equipment», c'est-àdire une quantité de présents ayant une valeur supérieure à celle du "common equipment» reçu par la plupart des individus. De plus, certains individus, notamment les chefs, obtiennent des présents d'une valeur encore plus importante ${ }^{24}$. Mis à part ces distinctions, les Amérindiens reçoivent des textiles, des couvertures, des munitions et divers objets et outils servant à l'agriculture et à la pêche ${ }^{25}$.

\section{L'IMPRÉVOYANCE AU SEIN DES DÉBATS ENTOURANT LA COMMUTATION DES PRÉSENTS PENDANT LES ANNÉES I820 ET I830}

Le premier pas franchi par l'État impérial britannique dans la transformation du rôle des présents dans ses relations avec les Autochtones survient immédiatement après la fin de la guerre de 1812-1814. En raison des hos-

23. Ce pourcentage est basé sur l'étude approfondie de Douglas McCalla sur l'agriculture dans le Haut-Canada et correspond aux recettes agricoles des années 1830 et 1840. La ferme haut-canadienne "moyenne» vend des produits d'une valeur de 45.5.8 1/2 livres cours de Halifax ( $£$ Hfx). Ce chiffre est la moyenne du revenu moyen des fermes analysées par McCalla pendant les années 1830 et 1840 à l'exception de celle qui a eu le plus important revenu commercial (presque cinq fois plus que la ferme ayant eu le deuxième plus important revenu commercial) et celle qui a produit le moins. Toutefois, comme remarque McCalla, il y a peu de raison de croire que les agriculteurs vendent beaucoup plus que la moitié de leur produit agricole pendant la période. Douglas McCalla, Planting the Province: The Economic History of Upper Canada, 1784-1870 (Toronto, University of Toronto Press, 1993), 84 et 271. La valeur des présents que reçoit la famille fictive $(3.7 .61 / 2 £ \mathrm{Hfx})$ vient du coût des présents distribués à chaque classe de récipiendaire vers 1843. La famille est constituée d'un guerrier, d'une femme et de trois enfants provenant de chacune des catégories d'âge définies par le département des Affaires indiennes (1 à 4 ans, 5 à 9 ans et 10 à 14 ans chez les filles ou 10 à 15 chez les garçons). Étant donné que les filles reçoivent des présents d'une plus grande valeur, le montant des présents pour chaque tranche d'âge est la moyenne des présents distribués aux filles et aux garçons, donnant ainsi une famille de trois enfants sans genre. Appendice $\mathrm{n}^{\circ}$ 59 dans Canada, «Report on the Affairs of the Indians in Canada», 1847. Le taux de conversion des livres sterling aux livres Halifax est de $1 £ \mathrm{stg}=1,1111 £\left(1.2 \cdot 2^{2} / 3 £\right) \mathrm{Hfx}$. A. B. McCullough, Money and Exchange in Canada to 1900 (Toronto, Dundurn Press, 1984), 292.

24. Appendice no. 59 dans Canada, "Report on the Affairs of the Indians in Canada", 1847.

25. Pour une liste des biens distribués à l'île Drummond dans le Haut-Canada pendant les années 1820, voir Appendice $n^{\circ}$ 60, dans ibid. Pour les biens distribués au Bas-Canada en 1830, 1834 et 1836, voir Appendice $\mathrm{n}^{\circ} 57$ dans ibid. Pour la liste d'objets distribués dans le Haut-Canada au début de l'été 1838 , voir Appendice $\mathrm{n}^{\circ} 58$ dans ibid. 
tilités entre la Grande-Bretagne et les États-Unis, les dépenses annuelles du département des Affaires indiennes augmentent de $200 \%$ pendant les années de guerre. Une partie importante de ces dépenses est destinée à l'achat des présents pour les alliés. En 1816, lord Bathurst, secrétaire d'État aux Colonies, tente de ramener le budget militaire à son niveau d'avantguerre en ordonnant, entre autres, au département des Affaires indiennes de ne pas dépasser le budget de 1811. En 1823, le département a largement devancé les attentes de Bathurst, réduisant ses charges annuelles à moins de la moitié des dépenses d'avant-guerre ${ }^{26}$. Même si le Colonial Office et le Trésor britannique cherchent à effectuer d'autres réductions budgétaires au département des Affaires indiennes, surtout en ce qui concerne les présents, aucune action concrète ne sera entamée en ce sens avant l'arrivée du nouveau secrétaire colonial, le vicomte Goderich, en 1827. En juillet 1827, Goderich demande au gouverneur en chef de l'Amérique du Nord britannique, George Ramsay, comte de Dalhousie, des renseignements détaillés sur «the precise expense of the Indian department, both in the salaries of officers, and in the amount of stores distributed to the Indians, with the view of effecting the reduction, and ultimately abolition of the establishment». Goderich ordonne également à Dalhousie de diriger

the heads of the department $[\ldots]$ to confer with leaders or chiefs of the Indians, who are entitled to annual presents, either as subsidies to their tribes, being independent, or as rewards for past services as subjects, or as retaining fees in nature of half-pay to those who have been employed in arms, or lastly in payment of lands ceded to His Majesty's Government, and to negociate with them for the commutation of such payments into money, such commutation to be fixed in British currency, and to be payable in the description of coin most agreeable to the chiefs.

En cherchant à convertir les présents distribués en nature en versements monétaires, avec leur suppression comme objectif ultime, le Colonial Office veut réaliser une "necessary measure of public economy and improvement ${ }^{27}$ ». Dalhousie répond que les Amérindiens du Canada recevraient "with the utmost alarm» la proposition de convertir les présents en espèces et s'oppose donc à cette proposition. Le gouverneur est convaincu que les Autochtones dépenseraient tout leur argent en achetant de l'alcool, soutenant même que le système des présents - axé avant tout

26. John Sheridan Milloy, The Era of Civilization - British Policy for the Indians of Canada, 1830-1860, thèse de doctorat (histoire), University of Oxford, 1978, 47-48.

27. "Copy of a Despatch from Lord Goderich to Earl Dalhousie», 14 juillet 1827, dans Great Britain, Aboriginal Tribes..., op. cit., 5. 
sur la distribution de biens utilitaires - avait été développé précisément afin d'éviter ce genre d'abus. Selon lui, «the system adopted in making useful presents as payment was intended expressly to avoid temptation ". Dalhousie rejette ainsi les ordres de Goderich puisqu'il considère «the proposed measure fully fraught with mischief to the Indians, no saving nor advantage possible to Government, and the future consequences of it dangerous in the extreme ${ }^{28}$ ». Malgré son désaccord, en juin 1828, presque un an après l'envoi de la directive du secrétaire colonial, Dalhousie finit par commander au major général Darling un rapport sur les Premières Nations du Haut et du Bas-Canada ${ }^{29}$.

De son côté, Darling, surintendant général adjoint des affaires indiennes depuis décembre 1826, s'intéresse à la distribution annuelle des présents dès janvier 1827, alors qu'il envoie un questionnaire sur le sujet aux quatre agents indiens résidant dans les villages amérindiens du Haut et du BasCanada $^{30}$. Ce document concerne la logistique de distribution ainsi que le caractère des présents, mais ne fait référence à aucun projet de monétisation. Le surintendant semble toutefois sceptique quant à l'utilité des présents lorsqu'il demande aux agents:

Does the use generally made by the Indians of the presents they receive justify the belief that their comfort is promoted by the liberality of Government in this particular, or do they for the most part dispose of the presents in exchange for liquor or other articles $^{31}$ ?

Cette question suggère qu'au début de son mandat, Darling croit que les présents, sous leur forme courante, peuvent être moins utiles que d'autres biens ou moins attrayants que l'alcool. Cela dit, le contenu du questionnaire ne permet aucune conclusion sur l'image qu'il se fait des Amérindiens. Même si les réponses des agents n’ont pas été recensées, Darling tente d'améliorer l'utilité et l'accessibilité des distributions annuelles, tout en réduisant les dépenses de la caisse impériale. De plus,

28. «Extract of a Despatch from Lord Dalhousie to Mr. Secretary Huskisson», 22 novembre 1827, dans ibid., 6.

29. «Instructions to Major-General Darling...», dans «No. 5: Copy Despatch and Enclosures from Lord Dalhousie to Sir George Murray», 27 octobre 1828, dans ibid., 31.

30. Dans le Haut-Canada les agents sont établis à l'île Drummond, à York (Toronto) et à Amherstburg. Le seul agent résidant au Bas-Canada se trouve à Saint-Régis (Akwesasne). Toutefois, Darling envoie ses questions à l'agent des Affaires indiennes à Montréal en charge des réserves de Kahnawake, du Lac-desDeux Montagnes (Kanesatake), de Saint-François (Odanak) et de Bécancour (Wôlinak). Henry C. Darling à Duncan C. Napier, 6 janvier 1827, BAC, RG10, vol. 20, 13831-13832, bob. C-11004 et Henry C. Darling à George Ironside, 6 janvier 1827, ibid., 13836-13837.

31. Henry C. Darling, «Schedule of Questions No. 2 respecting the Indians and those Presents Issued to them ", 6 janvier 1827, BAC, RG10, vol. 20, 13833-13835, bob. C-11004. 
cette enquête semble directement inspirer le rapport que Darling remettra à Dalhousie le 24 juillet 1828 .

Dalhousie transmet ce rapport en octobre suivant au nouveau secrétaire colonial, sir George Murray. Même s’il néglige la question du remplacement des présents par de l'argent comptant au Bas-Canada, Darling conclut que l'abolition ou la commutation des présents dans le HautCanada causerait de l'inquiétude parmi les Amérindiens sur les intentions ultimes de leur "père ", le roi. De plus, il affirme que l'argent n'a que peu de valeur aux yeux des Amérindiens, comparativement aux couvertures et aux munitions. Darling suggère de substituer une partie des présents déjà distribués par du matériel agricole et d'autres outils. Il propose aussi d'utiliser les revenus des cessions territoriales afin de financer l'achat de ces biens $^{32}$ et cite l'expérience «civilisatrice» de sir Peregrine Maitland dans le Haut-Canada où "One hundred pounds was so laid out in the case of the Mississaquas of the Credit River, and with the best effect ${ }^{33}$.»

Dans une lettre à Murray, datée de mai 1829, le gouverneur sir James Kempt, successeur de Dalhousie, reprend à son compte la plupart des affirmations de Darling. Il fait valoir qu'avant de transformer la nature des présents, le gouvernement devrait être persuadé que les Amérindiens ont fait suffisamment de "progrès " pour utiliser sagement l'argent:

I am of the opinion, however, that the Indians, when settled, would readily agree to the substitution of implements of husbandry, and seed, \&c. for many of the gaudy and useless articles which now compose their presents and which are daily falling in their estimation; but until a material improvement takes place in the habits of the Indians, it would be unwise to place at their disposal any commutation in money for those presents, of which they would in all probability make an improper use $e^{34}$.

Sans se préoccuper du point de vue des principaux intéressés, Kempt affirme donc qu'une fois établis dans des villages, les Amérindiens des deux Canada accepteraient sans hésitation des présents de nature agricole.

32. Sur les traités par lesquels les Premières Nations du Haut-Canada ont cédé leur territoire à la couronne britannique entre la fin du XVIII e et le milieu du XIX ${ }^{\mathrm{e}}$ siècle, voir J. R. Miller, Compact, Contract, Covenant: Aboriginal Treaty-Making in Canada (Toronto, University of Toronto Press, 2009), 66-122. Le premier traité de cession territoriale conclu entre les Amérindiens de l'actuelle province de Québec et la Couronne fut la Convention de la Baie James et du Nord québécois signée en 1975.

33. "Enclosure $N^{\circ} 1$ », dans «No. 5 : Copy Despatch and Enclosures from Lord Dalhousie to Sir George Murray ", 27 octobre 1828, dans Great Britain, Aboriginal Tribes..., op. cit., 29. Pour une analyse plus approfondie du rapport de Darling, voir John Leslie, Commissions of Inquiry into Indian Affairs in the Canadas, 1828-1858: Evolving a Corporate Memory for the Indian Department (Ottawa, Indian Affairs and Northern Development, 1985), 20-23.

34. "No. 8: Copy of a Despatch from Sir J. Kempt to Sir George Murray», 16 mai 1829, dans Great Britain, Aboriginal Tribes..., op. cit., 39 (souligné dans l'original). 
Par contre, d'ici là, l'argent ne pourrait avoir qu'une influence néfaste sur leur société. L'État devrait donc résister à toute tentative de commutation des présents.

En dépit du dédain à l'égard des "gaudy and useless " présents dont fait preuve Kempt dans sa lettre à Murray, les autorités coloniales adoptent un tout autre discours face aux Amérindiens. En effet, au lieu de prôner une transformation quelconque dans la nature des présents, les autorités coloniales insistent pour qu'ils ne soient ni supprimés ni modifiés. En juillet 1830, le secrétaire militaire de Kempt, George Couper, affirme dans un discours devant des chefs micmacs, hurons, malécites et abénaquis, que ces derniers reçoivent les présents en tant que droit:

Inow deliver to you by His Excellency's command, Lists of the equipment or presents established for the tribes in Lower Canada which were formed by your Friend the late Sir John Johnson in the year 1821, and approved by your Great Father in order that you may henceforward be thoroughly acquainted with the nature and quantity of the presents to which you are annually entitled ${ }^{35}$.

Couper informe donc les chefs que leurs communautés ont droit à des présents d'une quantité et d'une nature bien définies. Ce discours confirme l'affirmation faite dans une pétition signée quatre jours plus tôt par deux chefs abénaquis, un chef micmac et un chef malécite voulant que les présents constituent un droit découlant des cessions territoriales:

vos Pétitionnaires autrefois maîtres d'une grande partie du Canada, ayant cédé presque tout leur territoire, Sa Majesté, pour compensation ou plutôt pour une légère gratification, leur présentoit tous les ans les effets qui pouvoient ou leur être utiles ou qui leur servoient d'ornements.

En même temps qu'ils affirment avoir droit aux présents, les chefs soulignent l'incapacité de leurs communautés de subvenir à leurs besoins. Selon eux, ils éprouvent des difficultés à gagner leur vie à cause du "défrichement journalier des terres du Canada par les sujets de Sa Majesté » et «la marche de l'extinction de trois Nations». Cette pétition présente donc les trois nations comme dépendant de l'État afin de demander au roi de «bien les aider de tous ses moyens» en leur restituant les «effets qui leur étaient anciennement donnés» en tant que présents ${ }^{36}$.

35. Discours de George Couper aux Micmacs, Hurons, Malécites et Abénaquis, 13 juillet 1830, BAC, RG10, vol. 92, 37685-37688, bob. C-11468 (souligné dans l'original).

36. Pétition des Abénaquis, Micmacs et Malécites à James Kempt, 9 juillet 1830, BAC, RG10, vol. 25, 26202-26204, bob. C-11006. 
De façon éloquente, les chefs combinent deux arguments, un fondé sur le droit, l'autre sur le privilège, qui peuvent sembler tout à fait contradictoires. D’abord, ils affirment que la distribution des présents est un devoir du gouvernement britannique puis ensuite ils demandent que ces mêmes présents leur soient accordés en tant que charité, c'est-à-dire en tant que gage de la «bonté de la couronne». Dans ce cas précis, les deux discours sont entendus puisque l'État reconnaît ce droit, tout en acceptant de donner une aide matérielle additionnelle. En réponse à cette pétition, Couper leur annonce que :

Your father has been informed by the superintendent that the issue of a certain number of guns would now be very serviceable to you and that a portion of cloth, caddies, molton, ratteen, strouds, needles and serving thread would greatly contribute to your comfort, His Excellency will therefore direct some guns to be now delivered to you, and he will request your Great Father to add all the other articles to the List of presents which you annually derive from his Bounty ${ }^{37}$.

Tandis que les chefs abénaquis, micmacs et malécites n’abordent pas la question de la commutation des présents en argent, d'autres Amérindiens interviennent directement dans le débat. En 1831, Peter Jones, pasteur méthodiste et également chef de la bande des Mississaugas de la rivière Crédit, dans le Haut-Canada, présente à Goderich «a short account of the Indian people of Upper Canada, to whom I belong " ". Jones commente brièvement la distribution des présents avant de communiquer une demande du chef John Asance pour qu'une partie des présents des Chippewas de la baie Matchedash soit composée d'argent. Jones écrit qu'Asance "wishes to have something always in his pockets and never be empty, so that when he gets hungry he may put his hands into his pockets and find something jingling to buy bread with ${ }^{39} »$. Ainsi, Asance contredit la vision coloniale voulant qu'il existe une imprévoyance naturelle chez les Amérindiens. Il soutient plutôt que les présents en argent comptant seraient bien supérieurs à ceux distribués sous forme de biens matériels, puisque l'argent permettrait aux récipiendaires de combler leurs besoins au moment désiré.

Certains missionnaires, qui se présentent souvent en tant que porteparole des peuples autochtones, se prononcent sur la commutation des

37. Discours de George Couper aux Micmacs, Hurons, Malécites et Abénaquis, 13 juillet 1830, BAC, RG10, vol. 92, 37685-37688, bob. C-11468 (souligné dans l’original).

38. "Copy of a Letter from Mr. Peter Jones to Viscount Goderich", 26 juillet 1831, dans Great Britain, Aboriginal Tribes..., op. cit., 135.

39. Ibid., 136. 
présents. Par exemple, le révérend James Magrath, missionnaire de Toronto, envoie en 1829 un rapport concernant l'état du village des Mississaugas de la rivière Crédit à sir John Colborne, lieutenant-gouverneur du Haut-Canada. Fondé au début des années 1820 dans le cadre du programme de civilisation piloté par sir Peregrine Maitland, le village de la rivière Crédit sert de modèle pour plusieurs commentateurs contemporains qui cherchent à comprendre comment les Amérindiens peuvent être "élevés» au niveau des Euro-Canadiens ${ }^{40}$. Dans la première partie de son rapport, Magrath remarque que les Mississaugas préféreraient recevoir leurs présents annuels en argent:

They say that the articles they get are generally unnecessary, as they cannot use or wear out those they receive in a year; they frequently dispose of many articles at a great loss, particularly the guns. If they received one-half in cash they could procure many necessaries which (as they are now settled) they stand in need of, on more reasonable terms than they could do with the presents.

À la suite d'une demande de John Jones (frère de Peter Jones, qui est aussi instituteur de la bande de la rivière Crédit), Magrath joint à son rapport une brève note écrite en janvier 1829 , où il réitère cette demande. Magrath remarque que les Mississaugas visent ultimement à acheter du matériel agricole et piscicole $e^{41}$.

Fait étonnant, cette même note se retrouve également jointe à une autre lettre envoyée par Colborne au secrétaire colonial, au sujet de la gestion du département des Affaires indiennes dans le Haut-Canada. C'est la seule lettre écrite par un administrateur colonial à laquelle est joint un plaidoyer en faveur de la commutation trouvée aux archives. Toutefois, outre sa suggestion de distribuer de l'argent, le missionnaire se consacre à une description laudatrice du processus de civilisation entrepris au village. Le rapport soutient que les Mississaugas possèdent une économie en plein essor, due en grande partie au programme d'éducation et de conversion au méthodisme dont ils jouissent. En ce sens, Colborne se sert du rapport de Magrath, en dépit de son soutien à la commutation des présents, afin de faire la promotion du partenariat État-Église comme la voie de l'avenir pour la politique indienne.

40. Sur Maitland et l'établissement du modèle village mississauga, voir J. Leslie, Commissions of Inquiry..., op. cit., 12-17.

41. James Magrath, «Report of the State of the Indians on the River Credit... », dans «Enclosure No. 1», dans "No. 8: Copy of a Despatch from Sir J. Kempt to Sir George Murray», dans Great Britain, Aboriginal Tribes..., op. cit., 43. 
Après une période de relative inaction des autorités en ce qui concerne la commutation des présents, c'est en 1836 que l'État impérial, par l’entremise du baron Glenelg, secrétaire d'État aux Colonies, revient à la charge. Celui-ci envoie des instructions au gouverneur général de l'Amérique du Nord britannique, le comte de Gosford, et au lieutenant-gouverneur du Haut-Canada, sir Francis Bond Head. Glenelg les informe d'une résolution prise récemment par un comité mis sur pied par la Chambre des communes, pour étudier les dépenses militaires dans les colonies. Dans le but de réduire le budget du département des Affaires indiennes, cette résolution s'attaque particulièrement aux distributions annuelles de présents aux Amérindiens des deux Canada. Le comité se demande si «any Arrangement might not be made to dispense with such Distribution in the future, or to commute the Presents for Money ${ }^{42} »$. Londres vise encore une fois à réduire les dépenses du département des Affaires indiennes et ultimement à le dissoudre. Tandis que Goderich n'avait élaboré aucun échéancier dans ses ordres à Dalhousie en vue d'abolir le département, Glenelg indique qu'aucune action ne sera prise dans l'immédiat et que ses instructions visaient simplement à réunir des informations plus précises à l'égard des populations autochtones. L’État veut éventuellement instaurer des réductions fiscales sans toutefois mettre en péril l'avenir des Amérindiens: «I feel bound, affirme-t-il, after much Consideration, to express my Opinion that the Time is not yet arrived at which it would be possible, consistently with good Faith, altogether to discontinue the annual Presents to the Indians. » Les mots de Glenelg révèlent ici sa volonté d'éviter de créer un précédent sur lequel les Amérindiens pourraient éventuellement s'appuyer lors de revendications futures. Il décrit ainsi les origines historiques de la distribution des présents par les Britanniques dans des termes plutôt vagues, affirmant notamment que la pratique n'avait rien d'un droit fondamental pour les Autochtones, mais relevait simplement d'une coutume charitable établie avec le temps, ce qui laisse sous-entendre qu'elle pourrait éventuellement être abolie. Il écrit :

it is sufficient to observe, that the custom has now existed during a long Series of Years; that even in the Absence of any original Obligation a prescriptive Title has thus been created; and that this Title has been practically admitted by all who have

42. Cité dans «No. 1: Copy of a Despatch from Lord Glenelg to the Earl of Gosford», 14 janvier 1836, dans Great Britain, Copies or Extracts of Correspondence Since 1st April 1835, between the Secretary of State for the Colonies and the Governors of the British North American Provinces, Respecting the Indians in those Provinces (Londres, 1839), 1. 
been officially cognizant of the Matter, and that all agree in stating that its sudden Abrogation would lead to great Discontent among the Indians, and perhaps to Consequences of a very serious Nature ${ }^{43}$.

Glenelg ordonne aux autorités coloniales d'interroger les chefs amérindiens au sujet du remplacement des présents par de l'argent. Les deux gouverneurs sont aussi chargés de déterminer si les Amérindiens sanctionneraient «the Application of at least a Portion of the Sums now expended in the Purchase of Stores and Presents to the Erection of Schoolhouses, the Purchase of elementary Books, and the Payment of resident Schoolmasters, for the benefit of the Indian Tribes ${ }^{44}$ ». En voulant faire payer aux Autochtones leur propre éducation, Glenelg semble vouloir faire des économies tout en finançant le développement du système scolaire dans les communautés qui ne possèdent pas d'école. Glenelg soutient que la monnaie pourrait être bénéfique pour les Autochtones. Il ordonne ainsi à Gosford et à Head de procéder immédiatement à la commutation des présents, s'ils considéraient que «the Well-being of the Indians would be promoted by substituting an Equivalent in Money in lieu of the Articles at present issued ${ }^{45}$ ». Glenelg croit peut-être vraiment à la valeur civilisatrice de la monnaie, mais ses instructions paraissent toutefois avoir un caractère essentiellement rhétorique, visant à éviter de donner l'impression que l'État ne se préoccupe que de ses finances et non du bien-être des Autochtones. Quoi qu'il en soit des motivations de Glenelg, ses instructions s’inscrivent dans la lignée générale du Colonial Office qui justifie souvent ses actions en soulignant les avancées des peuples autochtones rattachés à l'empire britannique ${ }^{46}$. À la suite du «Slavery Abolition Act »

43. "No. 1: "Copy of a Despatch from Lord Glenelg to the Earl of Gosford”, 14 janvier 1836 ", dans ibid., 1. En ce sens, Glenelg fait écho à l'affirmation soulignant l'intérêt de continuer la distribution des présents de son prédécesseur. Selon le sous-secrétaire d’État aux Colonies, lord Howick, Goderich croyait que «the presents which, for a long series of years, have been annually distributed to these Indians, are due to them partly on the faith of treaties for the purchase of theirs lands; and for services rendered by their tribes in former wars, the remainder by custom so long established, that all the general officers, who have served in Canada, concur in opinion, that any sudden alteration of the system would excite great dissatisfaction amongst them, and be production of considerable inconvenience to the local governments». Howick cite Goderich dans une lettre envoyée à Stewart, secrétaire du Trésor. Extrait d'une lettre de Lord Howick à James Stewart, 14 février 1832, BAC, RG10, vol. 92, 37680-37684, bob. C-11468.

44. "No. 1: "Copy of a Despatch from Lord Glenelg to the Earl of Gosford”, 14 janvier 1836 ", dans Great Britain, Copies or Extracts of Correspondence..., op. cit., 3.

45. Ibid., 2.

46. Ce mouvement qui prône l'utilisation du pouvoir britannique pour améliorer la vie des peuples colonisés apparaît pour la première fois à la fin du XVIII ${ }^{\mathrm{e}}$ siècle dans un contexte où les projets visant la réforme morale et l'éducation scientifique chez les populations indigènes de l'Inde battent leur plein. Andrew Porter, "Trusteeship, Anti-Slavery, and Humanitarianism», dans Andrew Porter, dir., The Oxford 
de 1833, les autorités impériales font maintenant davantage appel au caractère humanitaire de l'empire même lorsqu'elles visent des objectifs, comme la réduction des présents, qui pouvaient, selon certains, être nuisibles aux populations colonisées ${ }^{47}$. Toutefois, Glenelg ne peut pas exiger l'obéissance des administrateurs canadiens, puisque la Grande-Bretagne ne gère pas son empire de façon fortement centralisée, au contraire de la France et de l'Espagne. En ce qui concerne l'élaboration et la mise en œuvre des politiques, la gouvernance britannique s'appuie plutôt sur la collaboration. L'approche du Colonial Office sur la question de la commutation est donc symptomatique de son style de gestion: il s'informe de la situation particulière tout en accordant aux colonies le droit de mettre en œuvre ou non sa politique ${ }^{48}$.

Head répond aux instructions de Glenelg comme l'avait fait Dalhousie une décennie plus tôt: il commence par ne pas en tenir compte, pour finalement refuser de les mettre en application. Dans sa réponse initiale, envoyée en août 1836, Head affirme que les instructions étaient arrivées trop tard pour les exécuter. Ainsi, au lieu de fournir les informations recherchées, il décrit plutôt son projet d'acheter l'île Manitoulin afin d'y implanter une réserve pour «those Indians, who are now impeding the Progress of Civilization in Upper Canada ${ }^{49}$ ».

Trois mois plus tard, Head envoie à Glenelg un mémorandum décrivant l'état de la population amérindienne du Haut-Canada et le fonctionnement du département des Affaires indiennes dans cette province. Ce document, cependant, présente les impressions et les observations de Head plutôt qu'un rapport détaillé. Au lieu de soumettre aux Autochtones la question de la commutation monétaire des présents, le lieutenantgouverneur se contente simplement d'offrir son avis:

I am not prepared to recommend that Money should at present be substituted for Presents to the resident Indians in this Province, - 1st, Because I think, unless good Arrangements were previously made, the Indians, from their improvident Habits, would in many Places be left destitute; and, 2dly, Because, without due Precaution,

History of the British Empire, The Nineteenth Century (New York, Oxford University Press, 1999), 3 : 198-221.

47. Sur l'abolition de l'esclavage dans l'empire et la capacité des autorités à sympathiser dans les discours officiels "with humanitarian goals even when disinclined or unable to promote them effectively", voir ibid., particulièrement 201-204.

48. Sur la gouvernance impériale britannique pendant le XIX siècle, voir Peter Burroughs, «Imperial Institutions and the Government of Empire», dans A. Porter, dir., The Oxford History of the British Empire, op. cit., $3: 170-197$.

49. " $\mathrm{N}^{\circ} 31$ : Copy of a Despatch from Sir F. B. Head, K.C.H., to Lord Glenelg», 20 août 1836, dans Great Britain, Copies or Extracts of Correspondence..., op. cit., 122. 
a Money Delivery to so many Men, Women, and Children might possibly be attended by very great Impositions s. $^{50}$.

En tenant pour acquis les «habitudes imprévoyantes» des Amérindiens, Head estime que les paiements en espèces risquent d'occasionner des frais supplémentaires.

De cette manière, Head semble transplanter ses expériences outreAtlantique en Amérique du Nord. En effet, de 1834 jusqu'à sa nomination en tant que gouverneur du Haut-Canada en décembre 1835, il a été commissaire adjoint de l'assistance publique dans le comté de Kent en Angleterre $^{51}$. Head devait mettre en œuvre la nouvelle Poor Law de 1834, une loi qui réformait en profondeur la provision d'assistance sociale au cour de l'empire ${ }^{52}$. En exprimant son scepticisme sur la capacité des Amérindiens de bien utiliser l'argent, Head reprend ses propres affirmations faites un an plus tôt en Angleterre lorsqu'il a dénoncé les «little shop-keepers » et les propriétaires des «beer-shops» qui profitaient « from that vast and hitherto unprotected mass of money, which has been collected nominally for the support of the poor ${ }^{53} »$. Head soutient donc que l'assistance monétaire ne constitue qu'une subvention cachée pour les marchands d'alcool. Tout comme d'autres observateurs coloniaux, le lieutenant-gouverneur puise dans un imaginaire, qui dépasse largement les frontières de la colonie, afin de calquer la prétendue imprévoyance des Amérindiens sur celle perçue chez des populations pauvres d'ailleurs ${ }^{54}$.

Contrairement aux autres administrateurs coloniaux, Gosford, lui, suit à la lettre les instructions du Colonial Office et ordonne, en octobre 1836, une enquête détaillée sur l'état des populations autochtones du Bas-

50. «No. 32: Copy of a Despatch from Sir F. B. Head, K.C.H., to Lord Glenelg», 20 novembre 1836, dans ibid., 129.

51. S. F. Wise, «Head, Sir Francis Bond», Dictionnaire biographique du Canada en ligne, www.biographi. ca/ 009004-119.01-f.php?\&id_nbr=5035 [consulté le 25 février 2012].

52. Sur la Poor Law, voir G. Himmelfarb, The Idea of Poverty, op. cit., 147-176.

53. Francis Bond Head, "Report of Sir Francis Bond Head to the Poor Law Commissioners for England and Wales ", $1^{\text {er }}$ août 1835, dans Great Britain, First Annual Report of the Poor Law Commissioners for England and Wales (Londres, W. Clowes and Sons, 1835), 166-167.

54. En décrivant les Amérindiens comme imprévoyants, Head est également influencé par des notions plus romantiques. En effet, il adopte certaines idées des Lumières quant à la noblesse des Amérindiens, tout en partageant la conviction courante au XIX ${ }^{\mathrm{e}}$ siècle que les Autochtones sont fatalement vulnérables aux vices des Européens. Cette vision lui a fait mettre en œuvre une politique calquée sur celle des ÉtatsUnis et en opposition directe avec celle de la "civilisation" généralement prônée en Amérique du Nord britannique où il encourageait les Amérindiens à se retirer devant l'avancée de la société coloniale, afin de mener une vie traditionnelle jusqu'à leur disparition inévitable. Theodore Binnema et Kevin Hutchings, "The Emigrant and the Noble Savage: Sir Francis Bond Head's Romantic Approach to Aboriginal Policy in Upper Canada, 1836-1838», Journal of Canadian Studies/Revue d'études canadiennes, 39,1 (hiver 2005): 115-138. 
Canada et sur la possibilité de remplacer les présents par de l'argent. Il fait part des résultats dans une série de lettres à Glenelg, débutant en novembre 1836 et culminant en juillet 1837 dans un rapport commandité auprès d'un comité du Conseil exécutif du Bas-Canada. Ce rapport décrit la plupart des activités du département des Affaires indiennes dans la colonie et fait le tour de la question de la commutation, fournissant des conclusions sur l'imprévoyance des Amérindiens qui marqueront pendant les décennies suivantes la politique indienne.

Afin de fournir les informations recherchées, les surintendants du département des Affaires indiennes pour les districts de Montréal et de Québec tiennent des conseils avec chacune des nations domiciliées du Bas-Canada à l'été 1836. Même si les documents générés à la suite de ces réunions sont plutôt modestes, ils permettent de saisir la vision des Amérindiens de la province sur les présents. Les six bandes interrogées par le surintendant du département pour le district de Montréal, James Hughes ainsi que les quatre bandes constituant la surintendance de Québec, sous l'autorité de Louis Juchereau Duchesnay, rejettent catégoriquement le remplacement des présents par de l'argent ${ }^{55}$. Ce refus repose sur deux arguments majeurs: d'abord, l'argent donné rendrait les membres les plus faibles de la communauté incapables de subvenir à leurs besoins, car ceux qui recevraient les paiements - les hommes - auraient tendance à les dépenser pour acheter de l'alcool; puis, on souligne que les présents constituent une manifestation concrète d'un ancien accord entre la Couronne et les Amérindiens de la vallée du Saint-Laurent, accord que le gouvernement ne pouvait modifier sans démontrer sa mauvaise foi.

Toutes les réponses des Amérindiens soutiennent d’une façon plus ou moins identique les problèmes que poserait la commutation. La réaction des Nippissings, des Algonquins et des Iroquois du Lac-des-DeuxMontagnes (Kanesatake) est, à cet égard, typique:

Tell our Father we want no Money from him; most of our young Men and many of the old ones would make bad use of it [...] Was our Father to give us Money instead of the Articles we now receive as our annual Presents, our Wives and Children would

55. Les informations soumises par Duchesnay sont beaucoup moins détaillées que celles de Hughes. Tandis que les rapports de Hughes font en moyenne une à deux pages pour chaque bande consultée, le rapport de Duchesnay couvre quatre bandes en moins d'une demi-page. Pour les rapports de Hughes, voir les annexes ("enclosures») 7 à 10 dans «No. 11: Copy of a Despatch from the Earl of Gosford to Lord Glenelg», 13 juillet 1837, dans Great Britain, Copies or Extracts of Correspondence..., op. cit., 41-46. Pour celui de Duchesnay, voir «Enclosure 11 in No. 11 », 22 août 1836, dans ibid., 46. 
be naked and miserable, and we Men unable to procure a Livelihood for them. We are sure our Father will find that we speak true, that he will listen to us, and continue the Issue of our Great Father's annual Bounty to us as heretofore ${ }^{56}$.

Les Iroquois de Caughanawaga (Kahnawake) vont encore plus loin et font la "preuve» que la distribution de l'argent par l'État aurait des effets néfastes. Le grand chef de la bande, Tekanasontie, décrit ainsi un événement survenu à Saint-Régis (Akwesasne), dans l'État de New York, lors du paiement des annuités monétaires par le gouvernement des États-Unis aux Iroquois:

The American Indians had upwards of 2,000 Dollars to receive. On that Day the Payment was made to us the Council-room was full of Tavern and Grog-shop Keepers, with their Account Books under their Arms, to receive our poor Brothers hard-earned Money for nothing but Rum, which they had advanced them on Credit. Upwards of 1,000 Dollars were paid to these Rum Sellers ${ }^{57}$.

Tekanasontie affirme donc que la distribution de l'argent ne servirait que les intérêts des marchands d'alcool.

En plus d'affirmer unanimement que la substitution des présents par de l'argent représente une menace pour les membres les plus vulnérables de leurs communautés, tous les chefs consultés soulignent l'importance des présents en tant que pilier de leur relation avec l'Empire britannique. Toutefois, les Amérindiens questionnés présentent deux visions distinctes de cette distribution, chacune s'appuyant sur une lecture différente des réalités historiques. À l'été 1836, les chefs des Iroquois d'Akwesasne semblent être les seuls à croire jouir d'un droit immuable à de tels présents. «Saro Oriwagati, the oldest Man and Chief of his Tribe (i.e. Ninety-four Years of Age)» fait valoir ce point de vue en affirmant:

Father, I have outlived a great many Winters, and Three bloody Wars, in none of which did I ever find cause to doubt the good and faithful intentions of my Great Father the King towards us his Indian Children; and I cannot believe that he now thinks of breaking that Promise of his Forefathers, which was guaranteed to us when I was a young Man : "Presents so long as we shall remain a tribe. $\rangle^{58}$.

Cette affirmation s'inscrit parfaitement dans la pensée iroquoise de la période. Par exemple, en 1833, six grands chefs et treize guerriers de Kahnawake soutiennent que

\footnotetext{
56. "Enclosure 9 in No. 11 », dans ibid., 44.

57. "Enclosure 10 in No. 11 ", dans ibid., 45.

58. «Enclosure 7 in No. 11 », dans ibid., 41 (souligné dans l'original).
} 
depuis le Gouvernement du Général Carleton (Lord Dorchester) jusqu’à celui de Sir James Kempt, tous les Gouverneurs de ce Pays nous ont toujours assurés que nos Equippemens Annuels nous seraient conservés tant que nous Existerions, Et comme une reconnaissance de nos services passés et en meme tems comme une Garantie pour nos services à venir, lorsqu'ils seront réclamés par notre Père le Roi ${ }^{59}$.

Selon les Iroquois, les présents dépassent donc le statut de simples objets distribués par l’État, puisqu'ils incarnent un engagement solennel de la Couronne envers les Amérindiens. Par conséquent, leur distribution ne pourrait jamais être légitimement révoqué $e^{60}$.

Les Abénaquis d'Odanak expriment une vision similaire mais moins nuancée, soutenant qu'il s'agit d'une «Sort of Remuneration for our past Services ${ }^{61} »$. Selon cette logique, les présents ne constituent pas un droit particulier aux Amérindiens, mais forment un paiement pour les services rendus aux Britanniques. Une telle vision, partagée par les Algonquins, les Nippissings et les Iroquois de Kanesatake ainsi que par les Iroquois de Kahnawake, rejoint celle des Iroquois d'Akwesasne sans pour autant affirmer la nature immuable des présents comme font ces derniers. Ce qui suggère une différence chez les Amérindiens quant à la stratégie à adopter en vue d'effectuer des changements à la politique indienne. En dépit de cette distinction, chaque communauté consultée par Hughes se montre profondément opposée à la commutation en fondant leur droit à la «bonté annuelle» des présents sur des arguments de nature historique. Les Algonquins, les Nippissings et les Iroquois de Kanesatake poussent cette logique à l'extrême en affirmant que la pratique française d'avant la Conquête a jeté les bases du système britannique ${ }^{62}$.

$\mathrm{Si}$, en 1836, les Amérindiens voient les présents comme une tradition solennelle, c'est en partie le fruit des efforts britanniques. En 1822, l'agent des Affaires indiennes de Kahnawake, Nicolas-Benjamin Doucet, propose

59. Pétition des Iroquois de Sault-Saint-Louis à Matthew Whitworth Aylmer, 27 novembre 1833, BAC, RG10, vol. 87, 34840-34843, bob. C-11466.

60. De plus, les présents servent à démontrer l'appartenance des individus à une communauté. Par exemple, George de Lorimier, un résidant de Kahnawake, revendique des présents non pas pour leur valeur économique immédiate mais pour leur valeur symbolique. Duncan Napier, le surintendant général du département des Affaires indiennes, écrit en 1837 qu'il serait ridicule de croire que de Lorimier cherche à recevoir les présents pour leur valeur matérielle, suggérant qu’il le fasse plutôt « with a view to remove the objections to his becoming a candidate for the situation of a chief of the Iroquois tribe, and eventually perhaps to his acquiring the control and management of the seigniory of the Sault St Louis ». Duncan C. Napier, "Observations on a letter from Mr. George de Lorimier», 24 October 1837, BAC, RG10, vol. 94, p. 38701-38704, bob. C-11469.

61. «Enclosure 8 in No. 11 », dans Great Britain, Copies or Extracts of Correspondence..., op. cit., 43.

62. "Enclosure 9 in No. 11 », dans ibid., 44. 
de distribuer les présents à tous les Amérindiens à date fixe, le 23 avril de chaque année. En plus d'être la fête de saint Georges, ce jour est aussi la date choisie pour souligner la naissance du roi à travers l'empire. Le secrétaire militaire, le colonel Henry Darling, ainsi que le surintendant du département des Affaires indiennes, sir John Johnson, appuient la proposition de Doucet. Cet appui commun est étonnant en vue de la rivalité qui existe entre Johnson, défenseur du clientélisme sur lequel le département a jusque-là été bâti, et Darling, partisan d'une bureaucratie axée davantage sur le mérite. Les deux hommes trouvent

that if the delivery of the Presents were attended with some form and Ceremony, it might tend to enhance their value in the eyes of these people, who should be taught to consider them rather as Tokens of the paternal regard of their Royal Father, than acknowledgments of past services ${ }^{63}$.

En dépit de cet accord, le projet de distribuer les présents au mois d'avril ne se réaliserait jamais, selon Johnson,

the most material Articles Such as Blankets, Gunpowder, Ball and Shot, are at that Season but little required by the Indians, and they have in consequence been induced to Barter Them to a considerable extent, whereby the Benevolent Intentions of His Majesty are frustrated, whereas when They receive Their Presents in the Fall of the Year, They find Them necessary for Their immediate Comfort and Support, and take care to preserve Them for that purpose ${ }^{64}$.

Malgré cet échec, l'accord initial que le projet suscite, même chez des rivaux politiques, souligne à quel point le symbolisme des présents ne préoccupe pas seulement les Amérindiens. Cela suggère que, tout en visant l'utilité maximale des biens distribués, les fonctionnaires de tout niveau cherchent à transformer les présents en véritables cadeaux, c'està-dire de les incruster dans l'imaginaire amérindien en tant que privilège au lieu d'un droit ou d'une rémunération.

Même si à l'été 1836 la plupart des communautés amérindiennes de la vallée du Saint-Laurent ne dépeignent pas les présents comme un droit immuable, deux de celles-ci changent de position afin de soutenir celle des Iroquois d'Akwesasne. En février 1837, après la fin des consultations, les chefs de trois villages membres des Sept Nations, les habitants de Kahnawake, Kanesatake et les Iroquois d'Akwesasne, envoient une péti-

63. H. C. Darling à Sir John Johnson, 30 mars 1822, BAC, RG10, vol. 15, 11885-11890, bob. C-11002. Dans sa réponse, Johnson cite intégralement ce passage. John Johnson à Henry C. Darling, 19 avril 1822, BAC, RG10, vol. 492, 30192-30194, bob. C-13340.

64. John Johnson à H. C. Darling, 18 août 1823, BAC, RG10, vol. 589, s.p., bob. C-13377. 
tion à Gosford pour protester contre la décision du département des Affaires indiennes de cesser la distribution des présents à tout enfant né après le $1^{\text {er }}$ mai de cette même année. La pétition s'appuie sur deux arguments. D’abord, la tradition de la distribution des présents provient des Français qui l'ont léguée aux Britanniques lors de la Conquête. Puis, cette pratique est un devoir de l'État impérial, qui ne saurait à juste titre être aboli :

Mon père, ces présents (puisqu'on nous a appris à les nommer ainsi) ne sont pas dans les faits des présents, c'est de la part du Gouvernement une dette sacrée promise à nos pères par les Rois de France pour les indemniser des terres qu'ils leur ont abandonnées, et confirmée par les Rois d'Angleterre depuis la cession du pays, et jusqu'à présent ponctuellement payée et acquitté $e^{65}$.

En dépit du ton conciliatoire des chefs (certainement une conséquence des exigences stylistiques imposées par la pétition), la simple affirmation, voulant que les Français aient entrepris la distribution annuelle des présents comme un dédommagement annuel et perpétuel pour des terres cédées, souligne la charge hautement symbolique et historique des présents.

Le département des Affaires indiennes poursuit également l'enquête afin de connaître l'avis des Amérindiens du Bas-Canada sur l'utilisation éventuelle d'une partie des fonds employés à l'achat des présents pour subventionner l'éducation de leurs enfants. Toutes les communautés rejettent cette question catégoriquement en invoquant des raisons identiques $^{66}$. Les Abénaquis d'Odanak répondent à la question:

Brother, tell our Father, that [...] we are well aware that they [les enfants d'Odanak] can but reap great Benefit from receiving an Education, but at the same time tell him, that the great Majority of the Abenaquois Tribe are so wretchedly poor, that they have not the Means of paying for the Instruction of their Children; that the Presents they

65. «Enclosure 17 in $\mathrm{N}^{-}$. 11: A Son Excellence Archibald Comte de Gosford... », dans Great Britain, Copies or Extracts of Correspondence..., op. cit., 62.

66. James Hughes ne pose pas cette question aux Algonquins, aux Nippissings et aux Iroquois de Kanesatake parce que le Séminaire de Saint-Sulpice gère et finance l'école de la communauté. «Enclosure 9 in No. 11 ", dans Ibid., 44. Duchesnay rejette totalement la pertinence de la question aux Amérindiens qui n'ont pas d'enfants qui fréquentent déjà l'école. Étant donné que les écoles existantes sont déjà financées, il ne voit aucune utilité à faire une enquête à ce sujet. Cependant, Duchesnay affirme que «they never would willingly contribute in any way towards paying Part of the Expenses of a Schoolmaster and other Expenses attending a School». "Enclosure 11 in No. 11 », 22 août 1836, dans ibid., 46. 
annually receive from their Great Father's Bounty are barely sufficient to protect them from the Cold ${ }^{67}$.

Bien qu'ils reconnaissent la valeur de l'éducation pour les enfants des communautés, les chefs affirment que leurs communautés ne sont tout simplement pas en mesure de la financer, surtout si cela implique une réduction dans la quantité des présents reçus. Les Iroquois d'Akwesasne, tout comme les autres bandes de la vallée du Saint-Laurent, soutiennent qu'ils seraient tout à fait disposés à envoyer leurs enfants à l'école, si l'éducation était payée à même les deniers publics: "[W]e hope in this respect to be put on a Footing with our Brethren the White Skins, who, we are informed, have their Children educated at the public Expense. If Schools are established amongst us on such a Footing, we will cheerfully send our Children to them ${ }^{68}$. » Tout en s'opposant au projet d'introduire l'argent au sein de leurs relations avec l'État, les Amérindiens de la vallée du Saint-Laurent ne voulaient aucun changement dans le système du financement de l'éducation si un tel changement nécessitait une diminution des fonds investis dans les présents. Les chefs justifient cette prise de position en s'appuyant sur l'imprévoyance imputée aux Amérindiens.

Contrairement au traitement réservé à la question de la commutation des présents par l'État colonial par le passé, le comité du conseil exécutif fonde ses conclusions, jusqu'à un certain point, sur l'opposition concrète des Amérindiens à la proposition, et non sur de simples suppositions ${ }^{69}$. Dans son rapport, le comité conclut qu'il ne faut ni substituer l'argent aux présents ni financer l'éducation à partir des fonds utilisés pour l'achat des présents. En arrivant à ces conclusions, le comité considère le statut légal des présents, tel qu'il a été invoqué par toutes les bandes consultées à l'été 1836. Même s'il affirme que les présents ne relèvent pas d'un droit spécifique accordé aux Autochtones, le comité indique que la coutume interdit aux autorités de supprimer ou de modifier leur distribution dans l'immédiat. Le rapport soutient même que les présents encouragent la pauvreté des Amérindiens, mais suggère le maintien de la distribution, car le comité ne voit aucune façon d'abroger les présents sans infliger davantage de souffrance. Les devoirs de l'empire obligent les autorités à s'assurer qu'aucune suppression des présents ne soit entreprise avant que les

67. "Enclosure 8 in No. 11 ", dans ibid., 43.

68. "Enclosure 7 in No. 11 ", dans ibid., 42.

69. «Enclosure in No. 11. To His Excellency the Earl of Gosford... Report of a Committee of the Executive Council... », 13 juin 1837, dans ibid., 28. 
Amérindiens soient "élevés» au-dessus de leur condition actuelle d'impuissance.

[T] his System, by fostering their natural Improvidence, by estranging them from the ordinary Pursuits and Industry of civilized Life, and teaching them to consider themselves as under a special Tutelage of the Crown, and in dependence upon it, has further strengthened their Claim to a Continuance of it until they shall be raised above their helpless Condition to which it has mainly contributed to depress them ${ }^{70}$.

Soulignant les effets néfastes des programmes d'aide étatique, le comité croit que seul le recours au marché peut briser la dépendance des Amérindiens à l'égard de l'État. Quel que soit l'avis du comité quant à la meilleure façon d'améliorer la condition matérielle des Autochtones, Gosford endosse entièrement les conclusions du rapport ${ }^{71}$.

\section{L'HÉGÉMONIE IDÉOLOGIQUE DE L'IMPRÉVOYANCE À PARTIR DE LA FIN DES ANNÉES 1830}

Rapidement après avoir été entériné dans le rapport final du comité, l'argument selon lequel les présents jouent un rôle central dans la paupérisation des Amérindiens refait surface outre-Atlantique où il est adopté par un groupe humanitaire très influent sur la scène politique impériale. En 1837, à la suite de l'émancipation des esclaves dans les colonies quatre ans plus tôt, des militants de la triomphante Anti-Slavery Society fondent la Aborigines' Protection Society (APS), afin d'investiguer et de publiciser les abus envers les Autochtones dans le but de faire adopter une politique impériale inspirée de son programme philanthropique ${ }^{72}$. En 1839, un comité de l'APS produit un rapport sur les affaires indiennes dans le HautCanada qui, comme celui du conseil exécutif du Bas-Canada, conclut que les présents ont rendu les Amérindiens de la province dépendants de l'État:

the ultimate object which has been aimed at in these grants, whether made a payment for land, or in consideration of service performed, has been to secure their allegiance, and to retain them under our control as a body of auxiliary troops. Our presents have therefore been such as would gratify their savage tastes or minister to their immediate wants, or enable them to pursue their original mode of life, as wandering hunters, without even the exercise of their own rude arts, by which their forefathers were

70. Ibid., 27-28.

71. "No. 11: Copy of a Despatch from the Earl of Gosford to Lord Glenelg», 13 juillet 1837, dans ibid., 25.

72. A. Porter, "Trusteeship, Anti-Slavery, and Humanitarianism», loc. cit., 209. 
supplied with articles of clothing, and the instruments of hunting and defence. With increasing difficulties they have become increasingly helpless and dependent $t^{73}$.

Le comité de l'APS appuie ses conclusions sur la correspondance coloniale-impériale au sujet des présents, notamment sur la lettre que Kempt envoie à Murray en 1829, soutenant que les fonds dépensés en présents seraient mieux investis en achetant des objets utilitaires ${ }^{74}$. Tout comme le comité du conseil exécutif du Bas-Canada, l'APS soutient que l'État est en partie responsable du développement de l'imprévoyance chez les Amérindiens. Pour remédier à cette dépendance, le comité conseille à l'État de fournir de l'assistance matérielle aux Autochtones jusqu'à ce qu'ils soient capables de subvenir eux-mêmes à leurs besoins. Autrement dit, l'APS propose essentiellement de perpétuer le même programme qu'il accuse d'avoir rendu les Amérindiens «increasingly helpless and dependent». Malgré la nature évidemment paradoxale de ce schéma, ni l'APS ni le comité du conseil exécutif ne semblent y voir un problème.

Dans ce contexte de consensus croissant des deux côtés de l'Atlantique, quatre autres commissions d'enquête se penchent sur ces questions entre 1839 et 1858 . Chaque commission fonde ses conclusions sur celles établies par ses prédécesseures (le major général Darling et le comité du conseil exécutif du Bas-Canada), constituant ainsi la «mémoire corporative» sur laquelle le ministère des Affaires autochtones et Développement du Nord Canada continue, encore de nos jours, de fonder sa légitimité 75 . De ces commissions, trois considèrent la question de commutation ${ }^{76}$, chacune réaffirmant les conclusions du rapport de 1837. Par exemple, dans son rapport sur les Amérindiens du Haut-Canada de 1839, le juge James Buchanan Macaulay écrit:

I concur with those who disapprove of a money commutation. It might (treating the presents as a dry matter of debt) be more convenient to pay in cash than in goods, but considering the motive and object, and, the well known indiscretion and folly of the

73. Aborigines Protection Society, Report on the Indians of Upper Canada (Londres, William Ball, Arnold, and Co., 1839), 24-25.

74. Le comité suggère, entre autres, que «All the payments due to the Indians whether for land, past services or for presents, which usage has sanctioned and taught them to expect as a right, should with their consent be so applied as respects the articles given, and the times and places of distribution, as may be most conducive to their real advantage and improvement. » Ibid., 28.

75. J. Leslie, Commissions of Inquiry..., op. cit. Voir aussi Michel Lavoie, «Politique sur commande: les effets des commissions d'enquête sur la politique publique et la politique indienne au Canada, 18281996 ", Recherches amérindiennes au Québec, 37,1 (2007): 5-23.

76. Tandis qu'il considère la substitution des présents traditionnels par des objets utilitaires, le comité No. 4 ne mentionne pas la commutation dans son rapport de janvier 1840. 
Indians no room is left for doubt on the subject. It is manifest that the money in itself can be of no benefit to them, it can only be useful to exchange for necessaries, and it may readily be supposed that if not enticed from the improvident holders with liquor excessive prices would be exacted from them for necessaries, of inferior quality, and undue advantages be taken of them in every way. Therefore as respects both commodity and prices and the real benefit and comfort of the receivers, the Government can best provide them with useful supplies such as clothing, implements of husbandry, fire arms, ammunition and food, in short almost anything but money ${ }^{77}$.

Dans un rapport soumis en 1844, la commission Bagot insiste sur " the well known indiscretion and folly of the Indians» et sur l'affirmation du comité du conseil exécutif en 1837 concernant le rôle de l'État dans la paupérisation des Amérindiens. "This reliance has doubtless had the effect of encouraging their natural indolence and improvidence; of keeping them a distinct people; of fostering their natural pride and consequent aversion to labour; and of creating an undue feeling of dependence upon the protection and bounty of the Crown.» Les commissaires concluent que «the majority of the Indians throughout the United Provinces, are still in such a state of actual destitution, and of incapacity to hold their place among the whites, that it would be inconsistent, both with justice and humanity, at present to withdraw such assistance from them ${ }^{78}$ ». Cette conclusion est également partagée par la commission Pennefather de 1858, même si cette fois la référence au comité du conseil exécutif est explicite :

Nous ne pensons qu'il soit possible de constater les conclusions auxquelles est arrivé le conseil exécutif dans l'admirable rapport qu'il a présenté à lord Gosford, en 1836. Il y soutenait que la position prise à l'égard des sauvages offrait de grandes facilités pour les instruire et améliorer leur condition; et que l'état de tutelle dans lequel on les maintenait tendait à leur faire regarder la couronne comme leur plus sûr appui, et à leur rendre dépendant d'elle ${ }^{79}$.

Ainsi, la description des Amérindiens imprévoyants par nature et affaiblis par l'assistance matérielle offerte par l'État sous forme de présents persiste jusqu'à l'aube de la Confédération.

77. «Report on Indian Affairs by J. B. Macaulay (typescript)», 1839, BAC, RG10, vol. 11206, file 3, $160-161$.

78. Canada, «Report on the Affairs of the Indians in Canada», dans Journals of the Legislative Assembly, Sessional Papers, Appendice T (Montréal, 1847), s.p.

79. Canada, «Rapport des commissaires spéciaux, nommés le 8 de septembre, 1856, pour s’enquérir des affaires des Sauvages en Canada » (Toronto, Stewart Derbishire and George Desbarats, 1858), 108. 


\section{CONCLUSION}

Même si de nos jours les présents distribués annuellement par l’État aux Premières Nations paraissent comme une curiosité historique, pendant la première moitié du XIX ${ }^{\mathrm{e}}$ siècle, ils constituent un enjeu de taille pour les autorités, les philanthropes et les Amérindiens. Chacun de ces groupes $\mathrm{y}$ voit quelque chose de différent. Les fonctionnaires à Londres les perçoivent d'abord comme de simples termes comptables, comme des objets trop coûteux à la caisse impériale. Pour leurs homologues coloniaux, il s'agit plutôt d'une mesure d'assistance sociale. Grâce à l'influence des philanthropes et des missionnaires, ces deux groupes finissent par se rejoindre autour du consensus voulant que les présents devraient être transformés en objets utilitaires qui encourageraient la «civilisation» des Amérindiens. Tous les intervenants constatent une certaine dégradation des conditions de vie des peuples autochtones, situation qu'ils relient, sans exception, à partir de la fin des années 1830 , à l'imprévoyance innée des Amérindiens. Pour les administrateurs et les philanthropes, cette imprévoyance se manifeste, entre autres, par l'incapacité apparente des Amérindiens à résister à la tentation de l'alcool. À cause de cette faiblesse, tous finissent par rejeter la proposition impériale de remplacer les présents distribués en nature par de l'argent.

Toutefois, les Européens et Euro-Canadiens ne sont pas les seuls à arriver à cette conclusion. La plupart des Amérindiens croient également au statu quo. Certains justifient leur opposition avec les mêmes arguments que les commentateurs d'origine européenne - à savoir, leur faiblesse bien connue pour l'alcool qui leur ferait gaspiller inévitablement tout argent comptant placé entre leurs mains par l’État. Mais le simple fait que les Amérindiens emploient la même justification ne veut pas dire qu'ils sont convaincus de son bien-fondé. Du point de vue autochtone, la crainte de dépenser tous les fonds dans l'alcool semble effectivement secondaire par rapport à la peur de perdre les présents. Cette deuxième peur est le fruit du lien symbolique rattachant les Premières Nations à la Couronne britannique. Dans ce contexte, l'imprévoyance est avant tout un élément discursif employé par les Amérindiens car il est susceptible d'influencer les autorités dans leur volonté de maintenir la distribution des présents ${ }^{80}$.

80. Cela ne veut toutefois pas dire que l'alcool n'est pas perçu comme un problème important par nombre d'Amérindiens. En effet, les chefs et les aînés éprouvent une réelle inquiétude face à la menace que présente l'alcool pour leurs communautés, comme en témoignent plusieurs commentaires cités ci-dessus. De plus, à partir de 1835 dans le Haut-Canada et 1860 au Bas-Canada, les législateurs s'appuient sur de tels énoncés, formulés sous forme de pétition, afin de justifier l'adoption des premières lois inter- 
Quelles que soient les raisons amenant chaque acteur à utiliser l'imprévoyance des Amérindiens, cette représentation justifie en partie l'intervention de l'État dans les communautés autochtones ainsi que leur mise en tutelle. Le discours prônant la "civilisation» des Premières Nations, tenu par les fonctionnaires et les philanthropes, s'appuie sur le consensus selon lequel les Amérindiens ne savent pas gérer leurs propres affaires. Au cours de la première moitié du XIX ${ }^{e}$ siècle, ce consensus devient une idéologie impliquant que les Amérindiens doivent être soumis à la tutelle de l'État, qui cherche à réparer la dépendance créée en partie par la distribution annuelle des présents. Ce consensus n'est pas, comme le prétend l'historiographie, le seul produit de la rencontre entre la volonté impériale de réduire les dépenses du département des Affaires indiennes, d'une part, et l'envie des autorités coloniales de "protéger» leurs alliés amérindiens, d'autre part ${ }^{81}$. En effet, la vision généralisée de l’imprévoyance et de la pauvreté explique tout autant la mise en tutelle des Premières Nations au cours du XIX siècle. Même si cette tutelle n'est pleinement réalisée qu'à partir du moment où le cadre législatif élaboré pendant les années 1850 et 1860 est mis en ouvre à grande échelle, grâce à l'augmentation exponentielle des effectifs du département des Affaires indiennes après l'acquisition de la Terre de Rupert ${ }^{82}$, l'idéologie la soutenant anime déjà la formulation de la politique indienne à partir des années 1820, tout comme l'image marquante de l'Autochtone imprévoyant.

disant la vente d'alcool aux Autochtones. Robert A. Campbell, «Making Sober Citizens: The Legacy of Indigenous Alcohol Regulation in Canada, 1777-1985 ", Revue d'études canadiennes, 42,1 (hiver 2008): 108.

81. Voir notamment J. S. Milloy, The Era of Civilization, op. cit., 84-97 et John L. Tobias, «Protection, Civilization, Assimilation: An Outline History of Canada's Indian Policy », Western Canadian Journal of Anthropology, 6,2 (1976): 13-30.

82. Sur ce processus, voir Brian Gettler, Colonialism's Currency: A Political History of First Nations Money-Use in Quebec and Ontario, 1820-1950, thèse de doctorat (histoire), Université du Québec à Montréal, 2011, 147-184. 